\title{
The Aircraft Structural Elements Corrosion Study Using Strain Gauge Method and Pulse Video Thermography
}

\author{
Ljubiša Tomić $^{1)}$ \\ Dalibor Jovanović2) \\ Stevan Jovičić ${ }^{2)}$ \\ Radovan Karkalić ${ }^{3)}$ \\ Goran Dikić ${ }^{3)}$
}

\begin{abstract}
Simultaneous influence of corrosion, static and dynamic loads on the elements of aircraft structures influence to a large extent their mechanical properties and the foreseen length of their service. The paper presents the influence of corrosion on physical and mechanical properties of the test bars made from materials for a wide range of applications which are used in aircraft structural elements manufacturing. Study comprises laboratory testing of bars for the simultaneous influence of corrosive environment, static and dynamic load. The problems are pinpointed regarding the use of strain gauges for continuous monitoring of the condition in real time. In addition, this paper deals with a modern non-destructive testing and evaluation system (NDT\&E), whose operation is based on thermal image processing. Thermographic method has been used to detect a hidden corrosion in the aircraft structure in real life. The study results have shown the possibility of NDT application in simple and quick detection of areas affected by corrosion that are visually invisible
\end{abstract}

Key words: corrosion, corrosion fatigue, corrosion testing, non-destructive testing, strain gauge, thermography, IR thermography, aviation application, aircraft structure, life-cycle testing.

\section{Introduction}

$\mathrm{T}$ HE most common cause of the failure is neither a fault in construction, irregular handling, bad selection of materials or manufacturing technology but the appearance of material fatigue which accounts for the cause of three quarters of all the operation failures. A large number of failures occur under the simultaneous influence of the environment and the loads to which the structural elements are exposed to during exploitation or under the influence of "stress corrosion".

The appearance of stress corrosion of metals is conditioned by the existence of the tensile forces, corrosive environment and degree of metal purity. It has been established from the experience so far that stress corrosion appears only in cases when tensile forces act on the structural elements. Stress in materials occurs as a consequence of both external and internal forces. Stress corrosion as a phenomenon is a complex process and it is determined by the nature and condition of the material, as well as by the character of the corrosive environment. A considerable influence on the tendency of metal for stress corrosion is attributed to the technological processing of metals. Increasing the degree of quality of metal surface processing reduces the possibility of occurrence of initial cracks which would make a favorable ground for damages to occur. The tendency of metals and alloys for stress corrosion depends also on the chemical composition and the structure of metal, the properties of individual components and the finish quality of the structural component surfaces.

In aviation industry there is a constant need for new approaches in the analysis of thermal and physical properties of materials [1,2] and also of the operating modes of the systems for non-destructive material testing and evaluation (NDT\&E) [3]. Thermography is a method which provides the analysis of thermo-physics features, based on the measurement of infrared radiation emitted by the specimen surface and its conversion into a visible image, thermogram. Pulse Video Thermography (PVT) is a NDT\&E method with a broad field of applications $[4,5]$. The application of thermography and other contemporary devices for control and non-destructive monitoring of the structure condition represent an advanced technique in the field of on condition maintenance and make a transition from conventional, ultrasound methods towards integrated systems for Structural Health Monitoring (SHM) [6-8]. Contemporary thermal imaging cameras [9-11], together with the special software for thermal image processing and analysis, can be applied on a mass scale in aviation industry using the Infrared (IR) thermography method. Except PVT, some other methods of IR Thermography can be used for NDT\&E, such as Lock-in Thermography (LT) and Pulsed Phase Thermography [12-17].

In the process of the airplanes preventive maintenance after a long operational usage possible corrosion on the

\footnotetext{
Military Technical Institute (VTI), Ratka Resanovića 1, 11132 Belgrade, SERBIA

2) Tehnical Test Center (TOC), Vojvode Stepe 445, 11000 Belgrade, SERBIA

3) University of Defence, Military Academy, Generala Pavla Jurišića Šturma 33, 11000 Belgrade, SERBIA

Correspondence to: Dalibor Jovanović; e-mail: jovcadach@hotmail.com
} 
construction under the protective paint can occur. This paper examines the negative effects of corrosion on the material for the aircraft production and methods of hidden corrosion detection by using IR thermography $[18,19]$. The aim of this paper was to experimentally confirm the negative effect of simultaneous action of corrosion, static and dynamic loads on the mechanical characteristics of material used for aircraft production. Another aim of the study is to confirm the possibility of simple and easy detection by NDT places affected by corrosion that are visually invisible.

Results of both experimental methods should demonstrate the necessity of the thermographic method application in the quality control of performed work on aircraft structures before and after the repair undertaken.

\section{Strain gauges method}

\section{Experimental setup}

The experiment was performed on the test bars made of AlMg2 aluminum. The test bar material has been selected as a typical material used in aviation for aircraft structural elements manufacturing.

The mechanical properties of the material are given in Table 1 [6].

Table 1. Mechanical properties of the test bar material

\begin{tabular}{||c|c|c|}
\hline $\begin{array}{c}\text { Modulus of elasticity, } E \\
{[\mathrm{MPa}]}\end{array}$ & $\begin{array}{c}\text { Tensile strength, } \sigma_{m} \\
{[\mathrm{MPa}]}\end{array}$ & $\begin{array}{c}\text { Density, } \rho \\
{\left[\mathrm{kg} / \mathrm{dm}^{3}\right]}\end{array}$ \\
\hline \hline 0,072 & 130 to 200 & 2,7 \\
\hline
\end{tabular}

Testing was performed on ten bars, dimensions $20 \mathrm{~mm} \mathrm{x}$ $100 \mathrm{~mm} \times 1 \mathrm{~mm}$. Nine bars were exposed to the influence of aggressive corrosive environment. Eight out of ten bars were exposed to the influence of static and dynamic load. Two bars were not exposed to the influence of any form of load and they were left outside the equipment for application of tensile force (one in room conditions, bar No.9, and one was exposed to the influence of salt fog, bar No.10). Four bars had a cut at the half of their length, representing an initial damage (Fig.1), $2 \mathrm{~mm} \times 1 \mathrm{~mm}$ in size (bars marked 5 - 8).

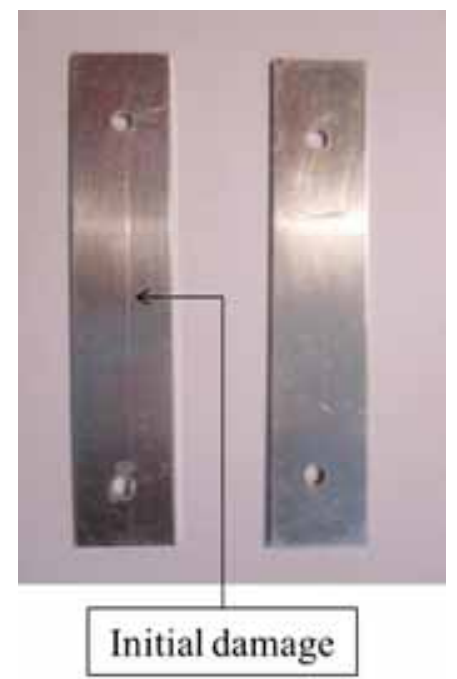

Figure 1. Test bars prior to testing (left bar with the initial damage)

The remaining four bars (Fig.2) did not have any damages (bars marked 1 - 4). Bars 1 through 8 had strain gauges attached which were coated by a protective lacquer layer in order to prevent the negative influence of salt fog, then they were set in the equipment for the application of static load.

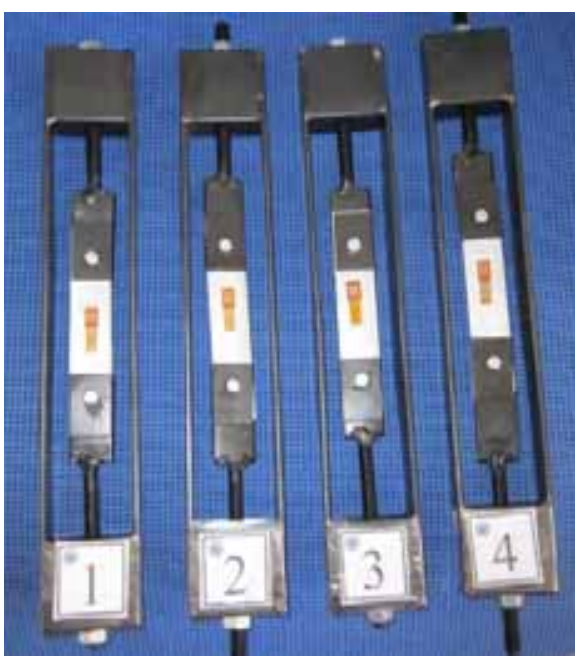

Figure 2. Test bars with strain gauge are set in the equipment for the application of tensile force

The applied load was of constant intensity. The strain gauges are manufactured by Hotinger, resistance $R=350 \Omega$ $\pm 0.35 \%$, factor $K=2.09 \pm 1 \%$. They were connected in $1 / 4$ Wheatstone bridge.

The testing bars marked with numbers 2 - 7 were then exposed to the influence of salt fog and room temperature in the following manner:

- 3 days at the temperature of $20^{\circ} \mathrm{C} \pm 5^{\circ} \mathrm{C}$ (the first cycle),

- 7 days at the temperature of $35^{\circ} \mathrm{C} \pm 2^{\circ} \mathrm{C}$ (the second cycle),

- 50 days at the room temperature, without the exposure to the influence of salt fog, and

- 3 days at the temperature of $35^{\circ} \mathrm{C} \pm 2^{\circ} \mathrm{C}$ (the third cycle).

Testing bars marked with numbers 1 and 8 were left outside the chamber all the time and were not exposed to the influence of salt fog.

\section{Results and discussion}

Table 2 shows the review of reading of stress changes registered on all 8 strain gauges during the testing of influence of salt fog on the bar mechanical properties. The test bars had the initial stress in $\mathrm{MPa}$, presented in the $2^{\text {nd }}$ column, Table 2.

Table 2. Stress condition during the test

\begin{tabular}{|c||c|c|c|c|c||}
\hline \multirow{2}{*}{ Test bar No. } & \multicolumn{7}{|c|}{ Stress condition [MPa] } \\
\cline { 2 - 6 } & Initial & 0 & I & II & III \\
\hline \hline 1 & 105 & 109 & 113 & 112 & 113 \\
\hline 2 & 105 & 114 & - & - & - \\
\hline 3 & 97 & 101 & 99 & 103 & 103 \\
\hline 4 & 102 & 104 & 43 & - & - \\
\hline 5 & 102 & 106 & - & - & - \\
\hline 6 & 99 & 115 & - & - & - \\
\hline 7 & 108 & 114 & - & - & - \\
\hline 8 & 102 & 107 & - & - & - \\
\hline
\end{tabular}

The initial, start stress condition is a stress condition after setting into the equipment for the load application. Column 0 represents a condition in which the bars were left one day before being set in the salt fog simulation chamber. Column I represents the first cycle and the results were recorded two times a day. In the column II are given the 
values after the second cycle which lasted 7 days, the results were recorded once a day. Column III represents the cycle lasted three days.

In the course of the exposure to the influence of salt fog, out of 7 tested samples which were in the salt fog chamber (the bars marked with numbers $2-7,9$ ), there were failures of strain gauges on seven bars (Fig.3).
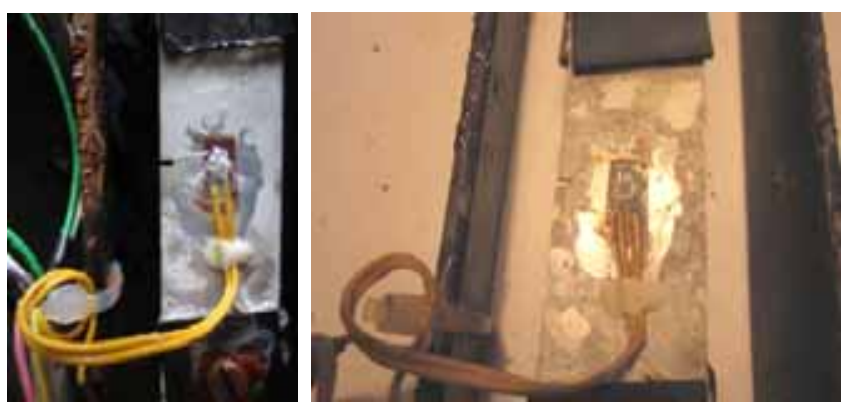

Figure 3. Damage at strain gauges after the exposure to the influence of salt fog

The failures occurred due to the degradation of the protective characteristics of lacquer layer, by which the strain gauges were coated at the beginning of testing. Only the strain gauge on the test bar No.3 remained functional, as well as the strain gauges on the test bars 1 and 8, which were outside the chamber in room conditions.

The review of experimental settings, static tensile force, salt fog and strain gauges failures during the tests is given in Table 3.

Table 3. Strain gauges failures during the test

\begin{tabular}{|c|c|c|c|c|c|c|c|c|c|c|c||}
\hline $\begin{array}{c}\text { Mark on AlMg2 test bar (20 x 100 x 1) } \\
\text { mm }\end{array}$ & 1 & 2 & 3 & 4 & 5 & 6 & 7 & 8 & 9 & 10 \\
\hline $\begin{array}{c}\text { Initial damage in the middle of the bar } \\
(1 \times 2) \mathrm{mm}\end{array}$ & & & & & $\bullet$ & $\bullet$ & $\bullet$ & $\bullet$ & & \\
\hline $\begin{array}{c}\text { Exposed to static tensile load } \\
\text { Exposed to the influence of salt fog, 3 } \\
\text { cycles }\end{array}$ & $\bullet$ & $\bullet$ & $\bullet$ & $\bullet$ & $\bullet$ & $\bullet$ & $\bullet$ & $\bullet$ & & \\
\hline $\begin{array}{c}\text { Exposed to vibrations, 13 cycles } \\
\text { Strain gauges attached }\end{array}$ & $\bullet$ & $\bullet$ & $\bullet$ & $\bullet$ & $\bullet$ & $\bullet$ & $\bullet$ & $\bullet$ & & \\
\hline $\begin{array}{c}\text { Failure of strain gauges due to the in- } \\
\text { fluence of salt fog }\end{array}$ & & $\bullet$ & & $\bullet$ & $\bullet$ & $\bullet$ & $\bullet$ & & & \\
\hline
\end{tabular}

\section{Pulsed Thermography method}

\section{Experimental protocol}

Setup for pulse flash thermography measurements comprises a heat source unit, thermal imaging camera and a computer, which stores data in real time. Fig. 4 shows the experimental setup for the PVT application of in reflex mode with a single light source that is positioned in front of the sample [20,21].

The SC620 infrared camera [22, 23], FLIR Systems, has been used for recording thermograms. The camera resolution is $640 \times 480$ pixels. It was positioned at the distance of $0.5 \mathrm{~m}$ from the sample surface. The camera sensitivity is $60 \mathrm{mK}$ at $30^{\circ} \mathrm{C}$, the field of view is $24^{\circ} \times 18^{\circ}$, the minimum focus distance is $0.3 \mathrm{~m}$, the spatial resolution is $0.65 \mathrm{mrad}$, the recording frequency is $30 \mathrm{~Hz}$ and the electronic zoom is $1-8 \mathrm{x}$ continuously. The detector type is a Focal Plane Array, non-cooled microbolometer of $640 \mathrm{x}$ 480 pixels. The spectral range of camera is 7.5 to $13 \mu \mathrm{m}$, whereas the temperature range is from $-40^{\circ} \mathrm{C}$ to $+1500^{\circ} \mathrm{C}$, with a precision of $\pm 2^{\circ} \mathrm{C}, \pm 2 \%$.
The camera is provided with the automatic correction of emissivity and atmospheric transmission based on the distance, atmospheric temperature and relative humidity. It simultaneously makes video and thermographic recordings or tracks. The ThermaCAM Researcher ${ }^{\mathrm{TM}}$ software for advanced analysis or recording on infrared sequences [20-21], is capable of measuring temperature at spots, on lines and in selected areas of various shapes and dimensions, as well as of showing isotherms using the gradation of grey or the palette of various colors and shades.

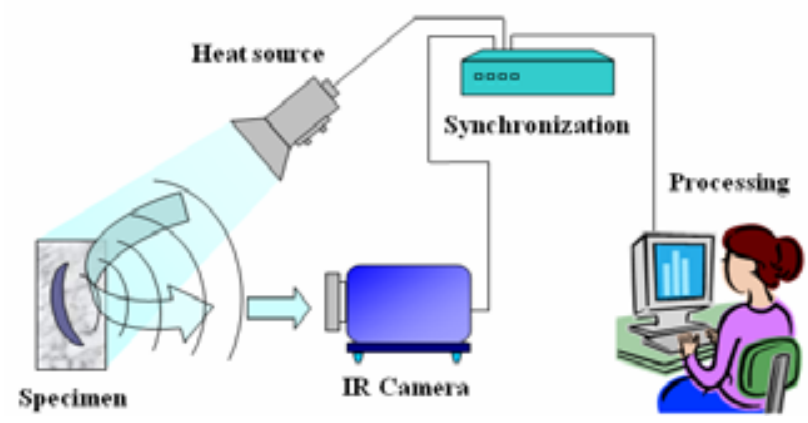

Figure 4. Experimental setup for active (optical) thermography inspection

The question is how to interpret the images obtained, so called thermograms. Image interpretation requires vast experience and expertise of the personnel dealing with the structural condition examination. However, even they need help. This help consists of making the calibration panels, the panels which will have all kinds of damages or defects that may be expected in practice made by the factory. Based on these calibration panels comparisons can later be made of the resulting images obtained during the examination of the structural elements.

The experimental setup for recording of sequences of the test sample No.4, is shown in Fig.5. By using of the ThermaCAM Researcher ${ }^{\mathrm{TM}}$ software, the measuring lines can be positioned in the middle of the specimen thermogram, vertically and horizontally at the spots where the fracture appeared [3, 21-23]. For a more precise analysis of the temperature variations on the tested specimen surface and its link to the mechanical properties, the detailed analysis has been conducted along the lines.

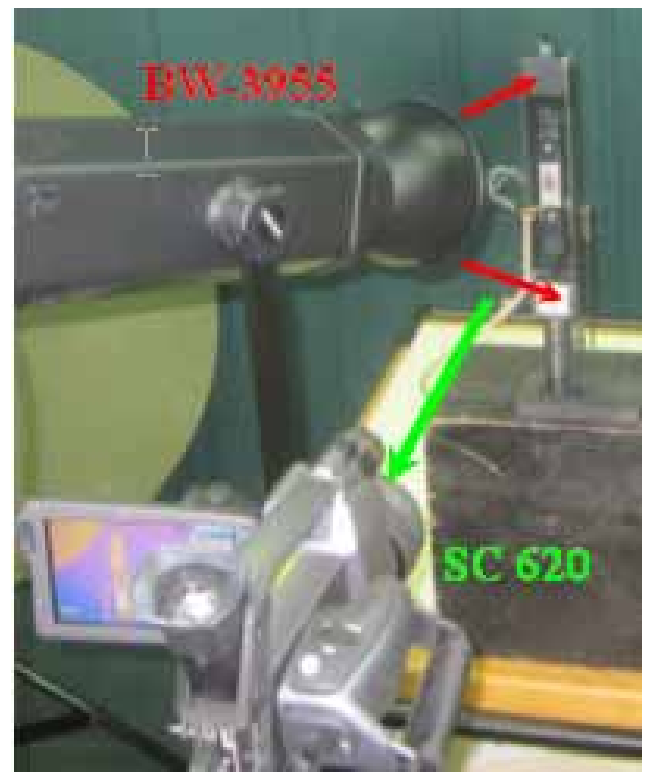

Figure 5. Experiment setup for recording of sequences of the test sample No.4 
Fig. 6 shows the thermograms of the $5^{\text {th }}$ and $7^{\text {th }}$ frame of the recorded NEW0098.SEQ sequence of the test sample No.4, cracking on the point of connection due to the stress corrosion. The left image shows thermogram before irradiation with the light impulse, while the right image shows the same sample after irradiation. The surfaces affected by corrosion are visible on the right image.
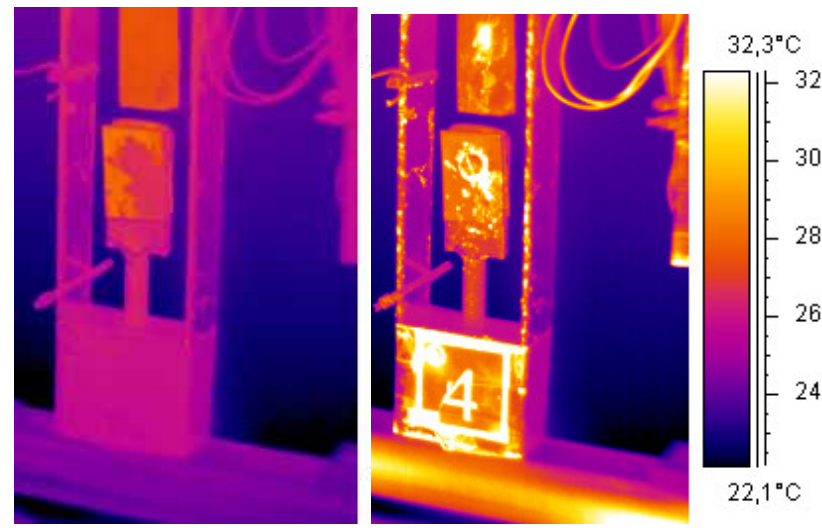

Figure 6. Thermograms of the test sample No.4, cracking on the point of connection due to the stress corrosion

The Pulse Video Thermography (PVT) set up involved the use of one flash lamp of $1500 \mathrm{Ws}$ as excitation source. The flash duration (at full power) flash lamps BW-3955 is $1 / 1400 \mathrm{~s}$. The light pulse duration was set at $0.7142 \mathrm{~ms}$. Some part of the IR radiation incident on the object surface is absorbed and transformed into a thermal energy, which propagates by thermal diffusion from surface inside the object. The flash lamps BW-3955 lamps are used for irradiation of the test sample No.4 and aircraft components whose thermograms are shown in Figures 6-10 and 11, respectively. An infrared SC620 camera from FLIR Infrared System, operating in the 7.5-13 $\mu \mathrm{m}$ spectral range was used. A sequence of 46 images was recorded over a period of three seconds after the flash impulse. In addition to the pulse light source, the halogen lamp FRESNEL QH1000 for continuous heating was used (Fig.7). The heating process is continued from 30 seconds to 1 minute. Thermal imaging camera is used to monitor changes in temperature during cooling.

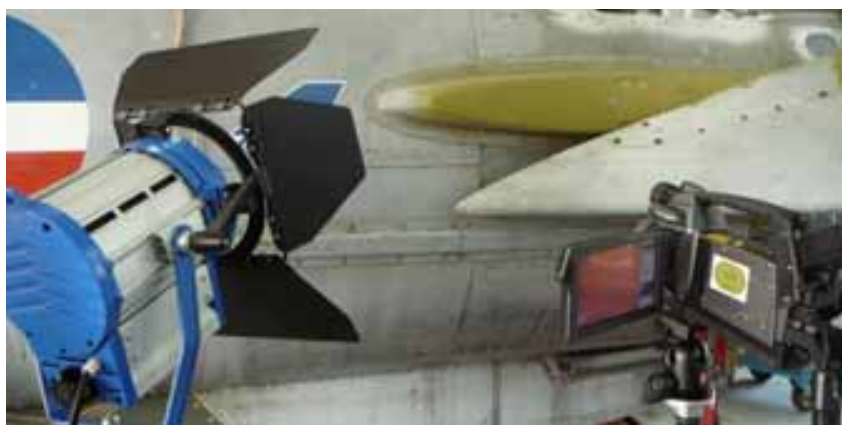

Figure 7. Testing of the tailplane-fuselage fillet at the root of the tailplane

Fig. 8 shows a frame of the recorded sequence after the use of flash light BW-3955 on the tailpane-fuselage fillet at the root of the tailplane. The warmer areas around the rivets where the corrosion process separated the paint from the basic material structure are clearly visible when the PVT method is used.

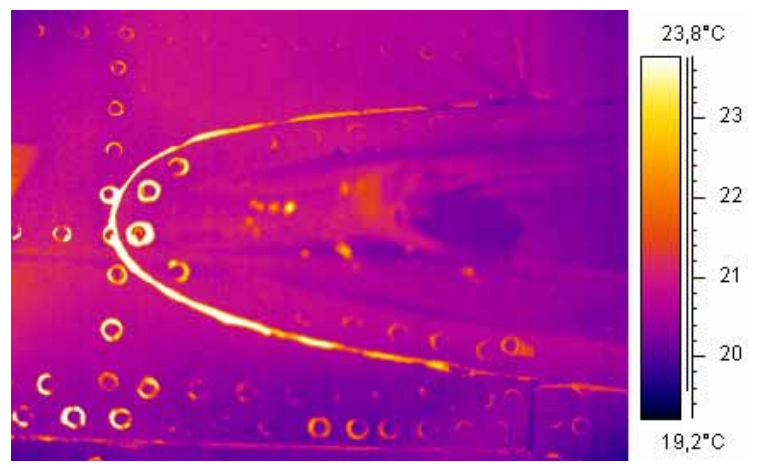

Figure 8. Thermogram of the $16^{\text {th }}$ frame of the recorded sequence NEW0168.SEQ after the use of halogen lamp

\section{Results and discussion}

Generally, to control the airplane in winter, due to a large difference in heat capacity [3, 18, 23], water and the material from which the aircraft is made, it is relatively easy to detect places where moisture collects. The presence of moisture is one of the conditions for the corrosion occurrence. Although the advantage of the PVT method is obvious under these circumstances, resolution of the IR camera, however, is not quite satisfactory, especially with regard to registration of discontinuity in the material.

In this part of the study, the comparison between various external sources of excitation in the PVT application, applied to examine cell-like elements of aircraft structure, is presented (eg. heat gun for intensive and simple heating tested aircraft surface; flash lamps for pulsed heat stimulation and halogen lamps for continuous and periodical heating). The results show the test bars and real structural elements which were subjected to examination. It can be concluded that the method of PVT is more suitable and more sensitive in comparison with the passive thermography. In addition to this, the passive thermography requires cooling of the entire aircraft after exploitation, while the active thermography is a considerably faster method and thus requires shorter time for examination.

Fig.9 shows two frames of the damage of surface protection at the point of connection between the counter weight and tailplane due to the influence of corrosion.
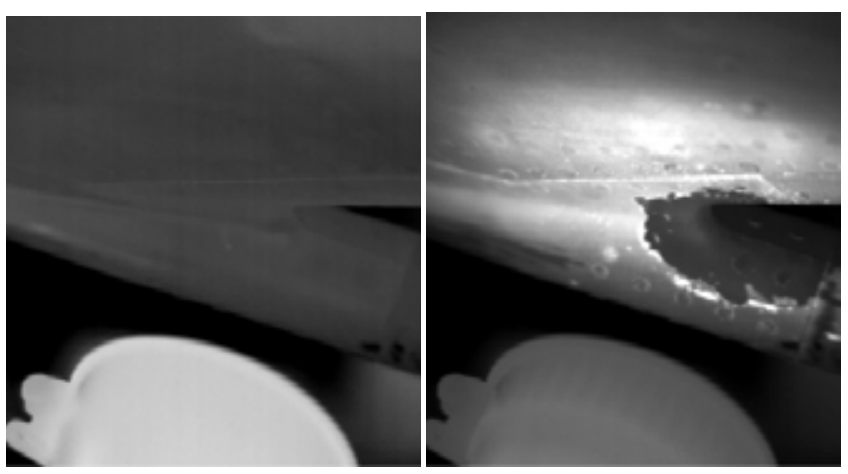

Figure 9. Thermogram, the damage of surface protection caused by the influence of corrosion

The left image shows the surface before irradiation with the light impulse, it can be seen that pixel temperature of the surface is approximately uniform and within the noise limits (the image is given at the level of gray where warmer places are lighter). On the right picture the same surface is shown after irradiation with the light impulse. 
Fig.10 shows $17^{\text {th }}$ frame in the recorded sequence NEW0134.SEQ before irradiation of the surface treated with light impulse. The surface of the part of the aircraft lining tested by the PVT method for subsurface corrosion. Rear frame at the structure of aircraft fuselage is made of steel, previously prepared, sanded and coated with protective paint. However, there has been a reforming of subsurface corrosion beneath the layer of paint due to inadequate and incomplete removal of corrosion. It is possible to observe in the picture the places where the sheet lining was riveted below the measuring line of pixels where the pixel temperature is LI01. The average pixel temperature along this line is $23.9^{\circ} \mathrm{C}$.
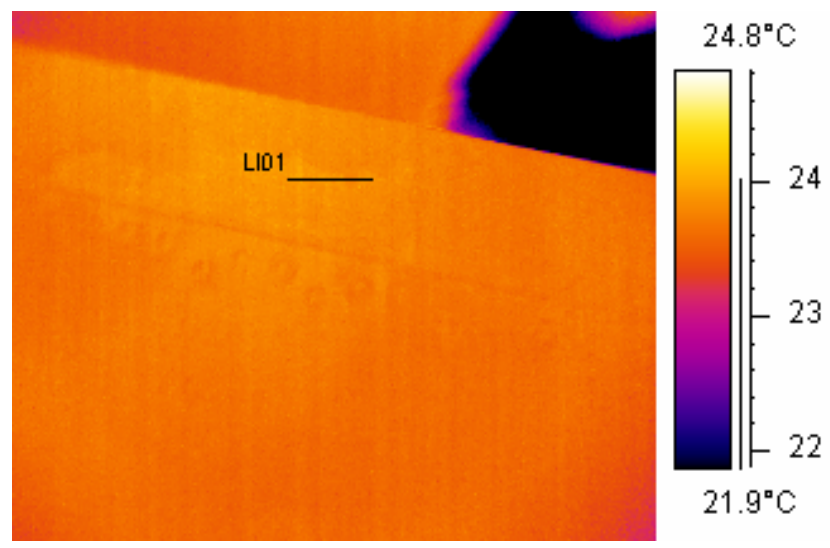

$21.9^{\circ} \mathrm{C}$

Figure 10. Thermogram of $17^{\text {th }}$ frame, exit edges of tailplane surface before irradiation

Fig.11 shows thermogram of $24^{\text {th }}$ frame in the recorded sequence NEW.SEQ, after irradiation with the light impulse. In this picture it is possible to observe two surfaces marked with dotted elipse-shaped lines where there are clearly visible light (warmer) surfaces beneath which there are areas with subsurface corrosion. The dotted line of the smaller circle shows the surface of scaled and fallen off paint, so that the corrosion can clearly be seen without the use of impulse thermography method. Larger dotted circular line shows painted surface beneath which there is no subsurface corrosion.

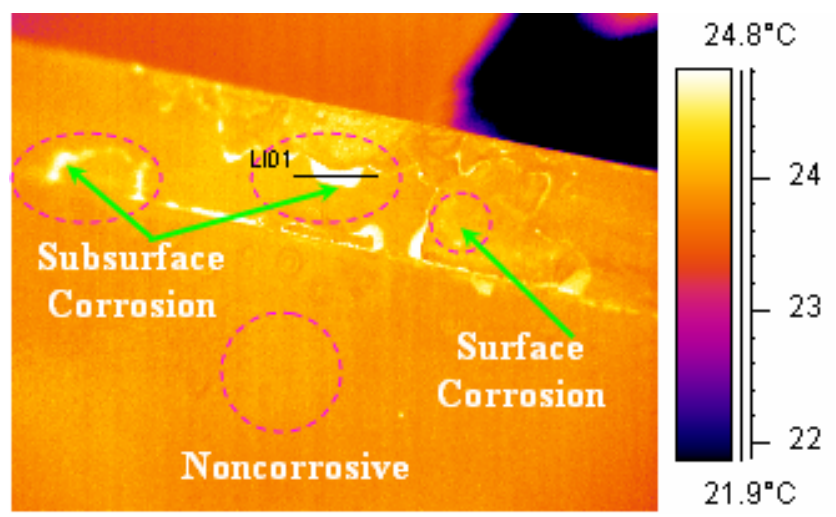

Figure 11. Thermogram of the exit edges of tailplane surface after irradiataion with the light impulse

Fig.12 shows the graphs of temperature profiles along LI01 measuring line, first for the cold surface of the aircraft lining $\left(17^{\text {th }}\right.$ frame) and then for the same surface heated $\left(24^{\text {th }}\right.$ frame).

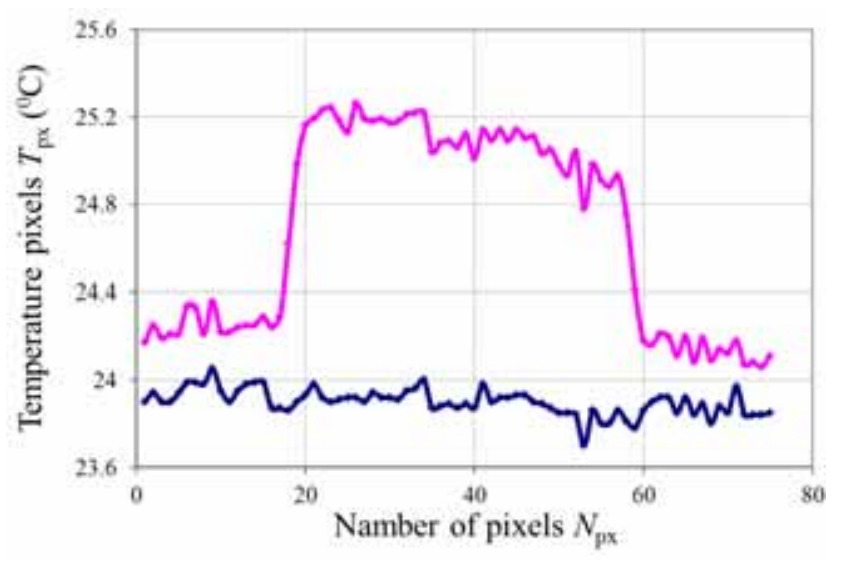

Figure 12. Temperature profile along measuring line LI01 of $17^{\text {th }}$ and $24^{\text {th }}$ frames

The upper curve represents the temperature profile along LI01 marker line of the heated surface presented on the thermogram in Fig.14. The changes in pixel temperatures of cold tail surface (the frame before irradiation with the light impulse) are within measured insecurity of $0.15^{\circ} \mathrm{C}$, while on the upper curve on the central part from pixels 16 to 60 the temperature is higher for $0.8-1^{\circ} \mathrm{C}$, which suggests the existence of the area with corrosion beneath the surface treated with protective coating.

The application of the impulse thermography enables fast scanning of large surfaces by suitable selection of powerful light flashes and contemporary thermal imaging camera.

Fig. 13 shows the graphs of temperature profiles in the function of number of frames within recorded sequence NEW0134.SEQ for three spots: SP01 above subsurface corrosion (green line) in the middle of LI01 line, spot SP02 in the middle of noncorrosive area and SP03, in the middle of surface corrosion.

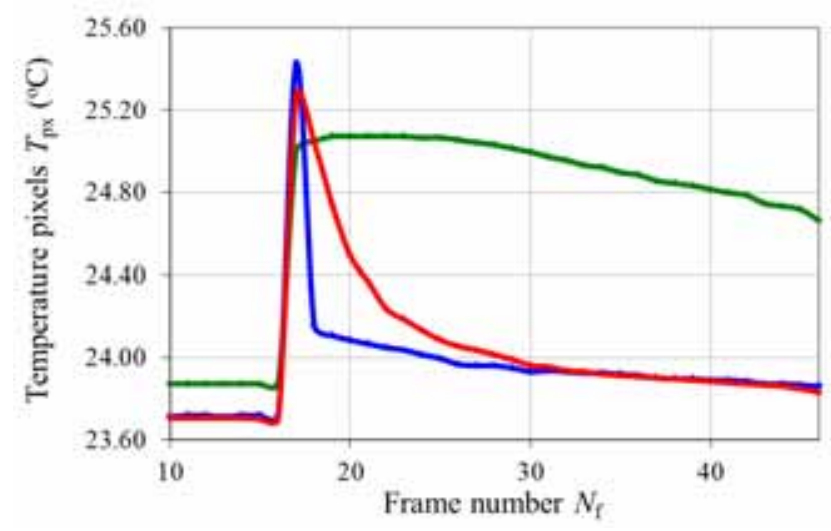

Figure 13. Temperature profile in time SP01, SP02

\section{Conclusion}

Study results indicate that combination of the influence of corrosion, static and dynamic loading in the form of applied vibrations led to a considerable degradation of the mechanical properties of the materials the bars were made of. Testing results have shown that the set strain gauges register deformations of test bars, in other words the changes in stressed state. The protection in the form of lacquer layer over the strain gauges proved inappropriate for the conditions to which the strain gauges are subjected 
in the chamber for testing of the influence of salt fog. There is a need for further research of this phenomenon and monitoring of the condition of the structural elements by means of both this and other nondestructive methods, such as IR thermography.

The fact that IRT is a non-contact technique is very important in this field, because this means that it is a painless procedure. Moreover, as the instrument is noncontact, it does not affect the result of the measurement and can be carried out remotely. Due to all of these advantages, thermography has been established as an effective tool in many different applications. This study has shown a simple application of infrared thermography in detecting subsurface places where corrosion can lead to weakening of the structure materials.

From simple tools for the surface stimulation we used heat gun (air temperature of $80^{\circ} \mathrm{C}$ to $650^{\circ} \mathrm{C}$ ), which gave excellent results for the specific applications. The paper considered optical stimulation techniques as well, using a flash lamp to light pulse stimulation and a halogen lamp for periodic or continuous heating. Using them, it was possible to stimulate larger or smaller areas depending on whether it applies one or more lamps.

We analyzed the benefits of IR thermography to quickly and accurately detect the presence of corrosion in aircraft structural walls. Active Infrared thermography is used to determine the complex structure and characterization of hidden corrosion damage in some parts of the aircraft structure. Recorded thermograms indicated there are corrosion damages in several places, which are examined in more detail by the Pulsed Thermography and "Strain gauges" methods.

In this study, some barriers in the application of PVT method were noticed, such as controlling the uniformity of heating cycle in space and time as well as emissivity variations of the sample surface. Uncontrolled convection losses influence affect the occurrence of the false contrasts and hence there is a problem of thermal images interpretation. The negative influence during experimental work has been showed due to the noise from the atmosphere absorption. Also, time development of contrast at metals surface is fast in comparison with the time resolution of standard thermal imaging cameras, which leads to the difficulties in registering the phenomenon.

\section{References}

[1] BADAWI,E.A.: Detecting defects in aircraft materials by nuclear technique (PAS), Surface Review and Letters, 2005, Vol.12, No.1, pp.1-6.

[2] ABDEL-RAHMAN,M.A.: Dislocation and defect densities by pat in 2024 aircraft material using two different activity sources, Surface Review and Letters, 2005, Vol.12, No.3, pp.463-468.

[3] MALDAGUE,X.P.: Nondestructive evaluation of materials by infrared thermography, John Wiley \& Sons, Inc., New York, USA, 2001.

[4] OSWALD-TRANTA,B.: Thermo-inductive crack detection, Nondestructive Testing and Evaluation, 2007, Vol.22, No.2, pp.137153.

[5] ZENZIGER,G. et.al.: Thermographic crack detection by eddy current excitation, Nondestructive Testing and Evaluation, 2007, Vol.22, No.2-3, pp.101-111.
[6] VERIGA,S.: Mašinski elementi I, Mašinski fakultet, Univerzitet u Beogradu, Beograd, Srbija, 1984.

[7] JOVIČIĆ,S.: Praćenje stanja metalnih elemenata strukture letelice s obzirom na uticaj naponske korozije, Doktorska disertacija, Vojna akademija, Beograd, Srbija, 2012.

[8] ILIĆ,Z., JOVANOVIĆ,M., PEKMEZOVIĆ,S.: Important aspects for extension of fighter plane service life by performing overhaul based on actual condition, Proceedings , $4^{\text {th }}$ International Scientific Conference on Defensive Technologies OTEH 2011, 6.-7. October 2011, Belgrade, Serbia, ISBN 978-86-81123-50-8, 2011, pp.183188 .

[9] GUOFENG,J. et.al.: Numerical Analysis of Influencing Factors and Capability for Thermal Wave NDT in Liquid Propellant Tank Corrosion Damage Detection, Measurement Science Review, 2013, Vol.13, No.4, pp.214-222.

[10] PEREZ,I., KULOWITCH,P.: Thermography for the characterization of corrosion damage, Proceedings, Expo 2000 NACE, Orlando, Florida, USA, 2000.

[11] KRAPEZ,J.C.: Deconvolution of the thermography images obtained on corroded parts by using the thermal modulation transfer function $(T M T F)$, Proceedings, $4^{\text {th }}$ International workshop on advances in signal processing for NDE of Materials, Quebec, Canada, 2001, pp. $1-6$.

[12] CLEMENTE,I.C., et.al.: Active infrared thermography with applications, IEEE Canadian Review - Spring/Printemps, 2008.

[13] LU,X. et. al.: A novel approach for flip chip solder joint inspection based on pulsed phase thermography, NDT\&E International, 2011, Vol.44, No.6, pp.484-489.

[14] ARNDT,R.W.: Square pulse thermography in frequency domain as adaptation of pulsed phase thermography for qualitative and quantitative applications in cultural heritage and civil engineering, Infrared Physics \& Technology, 2010, Vol.53, No.4, pp.246-253.

[15] MALDAGUE X.P, et. al.: Advances in pulsed phase thermography, Infrared Physics \& Technology, 2002, Vol.43, No.3-5, pp.175-181.

[16] WERITZ,R.F., et. al.: Investigation of concrete structures with pulse phase thermography, Materials and Structures, 2005, Vol. 38, No. 9, pp. 843-849.

[17] MALDAGUE,X.P, et. al.: A study of defect depth using neural networks in pulsed phase thermography: modeling, noise, experiments, Rev. Gén. Therm., 1998, Vol.37, No.8, pp.704-717.

[18] IBARRA-CASTANEDO C., MALDAGUE X.P.: Pulsed Phase Thermography Reviewed, QIRT Journal, 2004, Vol.1, No.1, pp.47-70.

[19] MAKSIMOVIĆ, S., VASIĆ, Z., DOŠIĆ, R.: Service Life Extension Program for Aircraft Structures, Scientific Technical Review, ISSN 1820-0206, 2015, Vol. 65, No. 3, pp. 46-54.

[20] MALDAGUE X.P., MOORE P.O.: Nondestructive handbook, Infrared Thermal Testing, $3^{\text {rd }}$ edition, ASNT Press, Columbus, Ohio, 2003, Vol. 3, p. 718.

[21] TOMIĆ, LJ., MILINOVIĆ, M.: Experimental research of limits for thermal modulation transfer function, Thermal Science, 2009, Vol.13, No.4, pp.119-128.

[22] TOMIĆ, LJ., ELAZAR, J., MILANOVIĆ, B.: Numerical simulation of the temperature field in pulse radiometric defectoscopy, Proceedings, $14^{\text {th }}$ International Conference on Aerospace Sciences \& Aviation Technology, 24-26. May 2011, Cairo, Egypt, 2011, 052TH, pp.99.

[23] DIKIĆ, G. et.al.: Characterization of periodic cylindrical subsurface defects by pulsed flash thermography, Surface Review and Letters, 2015, Vol.22, No.2, pp. 1550032 (11 pages).
Received: 01.10.2015. Accepted: 03.12.2015. 


\title{
Ispitivanje korozije u strukturi vazduhoplova primenom metode mernih traka i pulsne termografije
}

\begin{abstract}
Istovremeni uticaj korozije, statičkih i dinamičkih opterećenja na elemente vazduhoplovnih struktura u velikoj meri utiče na njihove mehaničke karakteristike i njihov predviđeni radni vek. $U$ radu je prikazan uticaj korozije na fizičkomehaničke karakteristike epruveta izrađenih od široko primenjenih materijala koji se koriste za izradu elemenata vazduhoplovnih struktura. Predstavljen je detaljan prikaz laboratorijskih ispitivanja epruveta na istovremeni uticaj korozivne sredine, statičkog i dinamičkog opterećenja. Ukazano je na probleme primene mernih traka za kontinuirano praćenje stanja u realnom vremenu. Takode, u radu je dat prikaz upotrebe savremenih metoda ispitivanja bez razaranja, baziranih na primeni pulsne termografije. Termografski metod je korišćen u svrhu detekcije skrivene korozije u strukturi vazduhoplova. Rezultati studije ukazali su na mogućnost primene NDI u procesu brze i jednostavne detekcije oblasti zahvaćenih korozijom koje su vizuelno nevidljive.
\end{abstract}

Ključne reči: korozija, korozioni zamor, ispitivanje korozije, ispitivanje bez razaranja, merna traka, termografija, IC termografija, primena u vazduhoplovstvu, struktura letelice, ispitivanje veka trajanja.

\section{Коррозионные испытания конструкции самолёта с помощью метода измерительных лент и импульсной термографии}

\begin{abstract}
Одновременное воздействие коррозии, статических и динамических нагрузок на элементы структуры самолёта в значительной степени влияют на их механические свойства и на их расчётный срок службы. В статье представлено воздействие коррозии на физико-механические свойства пробирок, изготовленных из материалов для широкого применения, которые используются для изготовления элементов структуры летательного аппарата. Здесь представлен подробный обзор лабораторных испытаний пробирок на одновременное воздействие коррозионной среды, статических и динамических нагрузок. Это указывает на проблемы применения измерительных лент для непрерывного мониторинга ситуации в режиме реального времени и преимущества при использовании "умных" материалов в процессе производства летательного аппарата. Кроме того, в статье описывается использование современных методов неразрушающего контроля (NDI), основанных на применении импульсной термографии. Термографический метод использован для того, чтобы обнаружить скрытые коррозии в конструкции летательного аппарата. Полученные данные свидетельствуют о возможности применения NDI в процессе быстрого и лёгкого обнаружений областей охваченных воздействием коррозии, которые визуально незаметны.
\end{abstract}

Ключевые слова: коррозия, коррозионная усталость, коррозионные испытания, контроль без разрушения (неразрушающий контроль (NDI)), измерительные ленты, термография, инфракрасная термография, использование в авиации, структура летательного аппарата, контроль срока службы.

\section{Examen de corrosion dans la structure d'aéronef par la méthode de jauge à ruban et par la thermographie pulsée}

\begin{abstract}
L'influence simultanée de la corrosion , des charges statiques et dynamiques sur les éléments des structure d'aéronef agit en grande partie sur leurs caractéristiques mécaniques et sur leur durée de vie estimée. Dans ce papier on a présenté l'influence de la corrosion sur les caractéristiques physiques et mécaniques des éprouvettes produites en matériaux largement appliqués qui s'utilisent pour la fabrication des éléments des structures d'aéronef. On a présenté en détail les tests réalisés au laboratoire pour les éprouvettes sur l'influence simultanée du milieux corrosif et de la charge statique et dynamique. On a indiqué les problèmes dans l'emploi des jauges à ruban pour le suivi continu de l'état dans le temps réel et les avantages que l'emploi des «matériaux intelligents" peut donner lors de la production des aéronefs. Dans ce papier on a présenté aussi l'application des méthodes modernes des tests non destructifs (NDE) basées sur la thermographie pulsée. La méthode de thermographie a été utilisée afin de détecter la corrosion cachée dans la structure d'aéronef. Les résultats de l'examen ont démontré la possibilité d'application de NDE dans le processus de la simple et rapide détection des régions affectées par la corrosion qui sont visuellement invisibles.
\end{abstract}

Mots clés: corrosion, fatigue de corrosion, examen de corrosion, examen sans destruction, jauge à ruban, thermographie, thermographie IR, emploi dans l'aviation, structure d'aéronef, examen de la durée de vie. 